\title{
Development roles: contingency and performance in alternative agriculture in Telangana, India
}

\author{
Andrew Flachs ${ }^{1}$ \\ Purdue University, USA
}

\begin{abstract}
Paul Richards invokes the metaphor of performance in agriculture to highlight the ways in which farmers improvise and draw on repertory knowledge to address new and unexpected problems in the field. This skillset helps farmers respond to shifting weather patterns or changing pest cycles, but it also helps farmers take advantage of new markets, technologies, and development interventions - a question of planning and context as much as improvisation in the moment. This article discusses two intervention failures and one success in Telangana cotton agriculture, arguing that such agricultural interventions succeed when farmers can align development performances with their own visions of development and agricultural success. In doing so, it offers a political ecology of farmer performance on two levels. First, it brings attention to the ecological and socioeconomic factors that inspire performances and structure farmer improvisations. Second, it argues that development initiatives must recognize their efforts as embedded within local agricultural planning and contingent on local calculations of social capital. In two ultimately unsuccessful interventions, farmers withdrew from programs that required investments of time and agricultural methods but did not underwrite important social and agricultural vulnerabilities identified by participants. In one successful intervention, farmers found that an NGO's willingness to respond to their agricultural needs and provide a stage for the cultivation of a local celebrity more than compensated for the new demands of non-certified organic agriculture. In a rural Indian context, where farming is a moral as well as agricultural process, the performance of a development identity is an integral part of performances and plans that guide farmer decision-making. Because these performances create a knowledge that cannot be separated from actors, roles, and stages present, these contingent performances ultimately have lasting impacts on the agrarian landscape.
\end{abstract}

Key Words: India, alternative agriculture, performance, knowledge

\section{Résumé}

Paul Richards invoque la métaphore de la performance en agriculture pour souligner la manière dont les agriculteurs improvisent et utilisent le savoir du répertoire pour résoudre des problèmes nouveaux et inattendus sur le terrain. Cet ensemble de compétences aide les agriculteurs à réagir aux changements climatiques ou aux cycles des ravageurs, mais aussi à tirer parti des nouveaux marchés, technologies et interventions de développement - une question de planification et de contexte autant que d'improvisation du moment. Cet article traite de deux échecs d'intervention et d'un succès dans l'agriculture cotonnière Telangana, en faisant valoir que de telles interventions agricoles aboutissent lorsque les agriculteurs peuvent aligner les performances de développement sur leurs propres visions du développement et de la réussite agricole. Ce faisant, il offre une écologie politique de la performance des agriculteurs à deux niveaux. Premièrement, il attire l'attention sur les facteurs écologiques et socioéconomiques qui inspirent les performances et structurent les improvisations paysannes. Deuxièmement, les initiatives de développement doivent reconnaitre que leurs efforts sont intégrés dans la planification agricole locale et subordonnés aux calculs locaux du capital social. Au cours de deux interventions finalement infructueuses, les agriculteurs se sont retirés des programmes qui nécessitaient des investissements en temps et en méthodes agricoles, sans pour autant garantir d'importantes vulnérabilités

\footnotetext{
${ }^{1}$ Dr. Andrew Flachs, Assistant Professor, Department of Anthropology, Purdue University, West Lafayette, Indiana, USA. Email: aflachs "at" gmail.com. Thank you to two referees and Simon Batterbury for your helpful comments. Research for this manuscript was funded with support from the National Geographic Society Young Explorer's Grant, the Jacob K. Javits Fellowship, the Volkswagen Foundation, and Heidelberg University. This is the fifth article in Andrew Flachs (ed.). 2018. "Performing development roles: theorizing agriculture as performance", Special Section of the Journal of Political Ecology 25: 638-764.
} 
sociales et agricoles identifiées par les participants. Lors d'une intervention réussie, les agriculteurs ont constaté que la volonté d'une $\mathrm{ONG}$ de répondre à leurs besoins agricoles et de fournir une scène pour la culture d'une célébrité locale faisait plus que compenser les nouvelles exigences de l'agriculture biologique non certifiée. Dans un contexte rural indien, où l'agriculture est un processus moral et agricole, la performance d'une identité de développement fait partie intégrante des performances et des plans qui guident la prise de décision des agriculteurs. Parce que ces performances créent une connaissance indissociable des acteurs, des rôles et des étapes présentes, ces performances contingentes ont des impacts durables sur le paysage agraire.

Mots clés: Inde, agriculture alternative, performance, connaissances

\section{Resumen}

Paul Richards evoca la metáfora del performance en la agricultura para resaltar las formas en que los agricultores improvisan y actúan con base en un repertorio de conocimiento para apuntar a nuevos e inesperados problemas en el campo. Estas habilidades ayudan a los agricultores a responder a patrones cambiantes del clima o variación en los ciclos de las plagas, pero también los ayuda a tomar ventaja de los nuevos mercados, tecnologías, e intervenciones de desarrollo - un asunto de planeación y contexto, tanto como de improvisación en el momento. Este artículo discute dos fracasos y un éxito en intervenciones en la siembra de algodón en Telangana, argumentando que tales intervenciones agrícolas funcionan cuando los agricultores pueden alinear performances de desarrollo con sus propias visiones de desarrollo y éxito agrícola. Para lograrlo, se ofrece una ecología política del performance agrícola a dos niveles. Primero, se atrae la atención a los factores ecológicos y socioeconómicos que inspiran performances y estructuran improvisación de los agricultores. Segundo, se argumenta que las iniciativas de desarrollo deben reconocer que sus esfuerzos están integrados en una planeación local agrícola y contingente dentro de los cálculos locales de capital social. En dos intervenciones que finalmente no tuvieron éxito, los agricultores se retiraron de programas que requerían inversiones de tiempo y métodos agrícolas, pero no cubrieron importantes vulnerabilidades sociales y agrícolas identificadas por los participantes. En la intervención exitosa, los agricultores encontraron que la voluntad de una ONG para responder a sus necesidades agrícolas y proveer un escenario para el cultivo de una celebridad local, hizo mucho más que compensar las nuevas demandas de la agricultura orgánica sin certificación. En un contexto rural de la India, donde el cultivo es tanto un proceso moral como agrícola, el performance de una identidad de desarrollo, es una parte integral de performances y planes que guían la toma de decisiones del agricultor. Como estos performances crean un conocimiento que no puede ser separado de actores, labores, y escenarios presentes, estos performances contingentes tienen, finalmente, impactos duraderos en el paisaje agrario.

Palabras clave: performance agrícola, planeación agrícola, desarrollo, algodón, India

\section{Introduction}

Visitors to the Institute for Research in the Semi-Arid Tropics (ICRISAT) outside of Hyderabad, Telangana, are greeted by a wax facsimile of a "typical Indian village" in the lobby (Figure 1). The image of the "typical Indian village" spurs scientists to action by creating technological interventions in agricultural practice, working to reduce the drudgery of plowing, weeding, sowing, or preparing seeds. Jean Baudrillard (1981) argued that in the contemporary postmodern global state, we have not only lost touch with the real in favor of the generation of models of reality, but that those same models create and subordinate the realities to which they refer. Importantly, such models are not merely artificial, because artificiality demands a recognition of the reality against which it is placed. Rather, the state of what Baudrillard calls hyperreality has eroded distinctions between the artifice and the real (Baudrillard 1981: 13).

The "typical Indian village" may help to motivate some Indian scientists, although many of ICRISAT's employees likely have none-too-distant relatives engaged in agricultural work. Nearly half of India is in some way dependent on agriculture (Sainath 2013) and agriculture has a deep connection to Indian citizenship (Ludden 1999; Pandian 2009). But for visiting non-Indian scientists who may not see or know much of rural India, the lobby serves a second, a more hyperreal purpose in subverting the real with the simulated, presenting an image of the drudgery to be overcome through the work of agricultural development. In the fields adjacent to the lobby, test plots provide proofs of concept to justify the spread of new technology, including GM cotton seeds (Qaim 2003) and organic agriculture (Forster et al. 2013). Such field trials assert their viability through 
these staged field demonstrations, even though these conditions rarely match those found in farm fields (Richards 1993; Stone 2011a). Still, the evidence from such models convinces not only trained scientists but visiting farmers to try an alternative agricultural system. While trained social scientists know to be cautious in taking these staged experiences as universal, demonstration farms and the charismatic and engaged individuals who run them are often asked to share their experiences in the development, corporate, and journalistic worlds. Such "show farmers" (Stone 2014) or "superlative sufferers" (Heller 2018) illustrate the potential of agricultural development programs and humanitarian interventions.

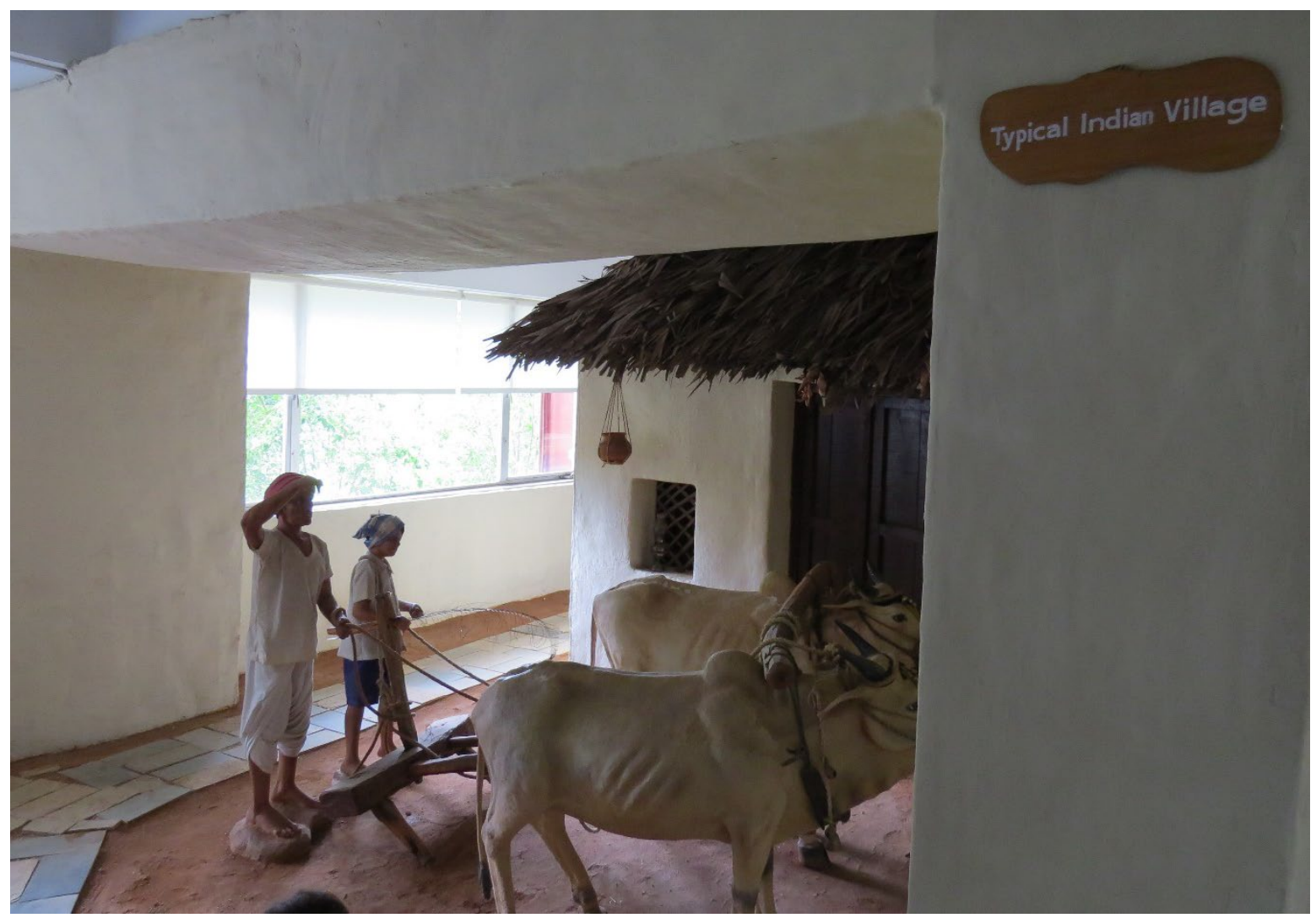

Figure 1: "Typical Indian Village" at ICRISAT. Photo by author.

Within the context of agricultural development, these kinds of performances serve a variety of different purposes for the farmers, programs, and documenters involved: they secure access to social and economic resources (Flachs 2017; Heller 2018);

i) they allow development subjects and aid recipients, broadly defined, to develop a narrative that orders their experiences (Escobar 2011; James 2010);

ii) they provide a means by which these people can shape development to their own interests and agendas (Flachs 2016);

iii) they emerge from improvisational responses to unexpected variables in social and agricultural life (Richards 1993) as well as from carefully planned engagements with development organizations and ecological constraints (Batterbury 1996);

iv) and, of course, they provide first-hand testimonials for larger institutions. 
Occurring as part of postcolonial development projects, each performance is enmeshed within a larger politics of developing in the 'correct' way from the perspective of states or development funding agencies. Correct can mean adopting chemical inputs and state partnerships (Gupta 1998; Vasavi 1999) or it can refer to state-driven moral imperatives to think of oneself as modern, mature, and scientific (Escobar 2011; Pandian 2011). While remaining critical of these performances at face value, this article explores how such performances lead participants in agricultural development programs to develop social and agricultural skillsets that reinforce these development interventions, or fail to do so. I argue that skill and performance are intertwined and contingent, and that both influence how farmers make agroecological decisions.

Paul Richards $(1989,1993)$ invokes the metaphor of performance in agriculture to highlight the ways in which farmers draw on a set of improvisational capacities that guide their response to new and unexpected problems in the field. Viewing agricultural performance in a broader lens that considers social, ecological, political, and economic constraints, this repertory knowledge helps farmers respond to shifting weather patterns, changing pest cycles, new markets, innovations, and development interventions - a question of planning and context (Batterbury 1996) as much as improvisation in the moment. This article discusses two intervention failures and one success in Telangana cotton agriculture, arguing that such agricultural interventions succeed when farmers can align development performances with their own visions of development and agricultural success. In two ultimately unsuccessful interventions, farmers withdrew from programs that required labor and infrastructure investments but did not underwrite important social and agricultural vulnerabilities in the villages. In one successful intervention, farmers found that an NGO's willingness to respond to their agricultural needs and provide a stage for the cultivation of a local celebrity more than compensated for the new demands of non-certified organic agriculture. The failure to align didactic instruction with existing patterns of social emulation has been shown to disrupt the spread of agricultural technologies (Stone 2016), a question of insufficient planning for farmers' social and agricultural needs. However, in a rural Indian context, where farming is a moral as well as agricultural process (Pandian 2009), the performance of a development identity is also an integral part of the improvisatory repertoire of knowledge that guides farmer decision-making. Because these performances create a knowledge that cannot be separated from actors, roles, and stages who employ that knowledge (Stengers 2010), these contingent performances ultimately have lasting impacts on the agrarian landscape.

I begin by exploring Richards' discussion of skill and performance, examining how this dramaturgical metaphor has been used within agricultural development as well as within theories of knowledge and subjectivity generally. I then explore how these performances may be considered contingent, drawing particularly on postcolonial and science and technology studies (STS) frameworks. That section concludes by summarizing how the reward structures of different kinds of development projects incentivize and constrain certain performances, and thus certain kinds of knowledge.

Then, I transition to my empirical data, discussing three case studies in agricultural development in South India, drawing on 16 months of fieldwork on cotton farms in Telangana, India. These initiatives, only one of which was ultimately successful, illustrate how farmers perform for different audiences and perform roles according to social and ecological rhythms in their lives. Through a combination of ethnography, interviews, and surveys with farmers, development workers, and agricultural scientists, I trace how performers and audiences align their interests and create mutually beneficial relationships. I also discuss what happens when they fail to do so. I conclude by exploring some of the stakes of such agricultural performances for the spread of development technologies, knowledge, postcolonial subjectivity, and the agrarian landscape.

\section{Agricultural performances, self, knowledge, and contingency}

Looking to the ways in which small farmers develop a series of adaptive, improvisatory strategies to confront agricultural problems, Paul Richards $(1989,1993)$ compares agriculture to a musical performance: like improvising musicians, farmers draw on repertory system of agroecological knowledge when making agricultural management decisions. By looking at the fields of smallholding farmers, we can observe a completed performance that matches not a design or intention so much as a response to the given context of weather or fertilizer price hikes. The salient factor for anthropologists is then not design logic so much as 
sequential adjustment, the ways in which an improvisatory skillset is put to use (Richards 1993: 67). This helps to explain why field trials, which eliminate the variabilities of farmer performance, are bad predictors for agricultural success in farmers' fields - this difference is akin to that between performance and rehearsal. Richards calls this system of knowledge and practice a set of "improvisational capacities" (Richards 1993: 62), reasoning that farmers must call upon a repertoire of experience and resources when managing the environmental, social, and economic variables of the farm.

Seminal scholars of smallholder agriculture and farmer decision-making agree that agriculture is best understood as a continued practice based in a series of adaptive strategies for managing agricultural diversity (Brookfield 2001) in long-term smallholder farming (Alcorn and Toledo 2000; Leslie and McCabe 2013; Sumberg and Okali 1997; Wilken 1987). When making a living that must satisfy market and subsistence needs despite unexpected socioecological problems, small farmers tend to have to do more and, thus, to have to know more (Netting 1993: 50). James Scott (1998) and Susanne Friedberg (2004), drawing on the work of Marcel Detienne and Jean-Pierre Vernant (1991), call this agricultural improvisation mêtis, referencing the knowledge of luck, cunning, and intuition that accounts for local-scale variations in practice-based knowledge.

Just as Richards, and Stone (2011a) after him, argued that field trials were poor predictors of agricultural success, Scott and Freidbeg's applications of mêtis draws attention to the same patch-and-mend knowledge necessary to practice sustainable agriculture in the field (Richards 1993: 70). This suggests that freedom to improvise, more than careful planning, is the most important factor in an intervention's sustainability. However, a political ecology framework would recognize that all improvisations are constrained by both political and ecological constraints outside of farmers' control: climate change, soil depletion, development funds, or local means to earn community status. As Batterbury (1996) argues in his expansion of Richards' work, the performance of this knowledge is not merely improvised on the spot but also actively planned to take advantage of ecological constraints like exhausted soils, socioeconomic constraints variables like capital availability, development organization opportunities, or the need to prove oneself by building a farm separate from the family land. In each case, the performance, and its myriad improvisations, must correspond with the needs of different audiences (development organizations, family members, neighbors) and stages (ecological constraints, development opportunities, social and economic pressures).

Because of its versatility, the metaphor of performance in social theory has taken on a variety of meanings, describing ritual roles and dramas that reflect power in society (Turner 1970, 1980), the performances that signify and enact that which is always and already there (Butler 1990), or the strategic presentations of self that help people navigate complicated social spaces (Goffman 1956, 1959). My use of the term here is further complicated because in agriculture, performance refers to the economic value or yield of a crop that a farmer grows. I recognize, from Butler's insights, that agricultural performance are subsumed within performativity, the presentations of self that are saturated with power and reproduce discourse around identity, enabling or disciplining subjects (Gregson and Rose 2000). As Butler showed, performances continually reinforce and can subtly reshape norms. In development, the performance of gratitude or of an identity aligned with a development program provides access to resources, such as the right pesticides or regular consultations with an extension institution. As this stage is further set by these new opportunities, the performance of that development identity disciplines members of the community who align themselves against development programs by ostracizing them from those social capital or material gains. Following Butler, such performances simultaneously create an authentic lived reality. There is no true, authentic self lurking behind these performances since selves and knowledges are fluid, in states of becoming or mutually composing with others (Haraway 2003; Latour 2010), and informed by a constantly produced relational web of obligations, actions, and discoveries (Ingold 2011; West 2012).

With these caveats, I employ the metaphor of performance to call attention to several aspects of agricultural development relevant to political ecology: the ways in which farmers adopt certain practices based on the response of different audiences, including demands of modernity from corporate and state actors as well as the need to be seen as a good and responsible farmer by the village community (Pandian 2009); how these presentations of self are contingent on the resonance of that interaction or one's assessments of risk and failure (Bardone 2013; Schieffelin 1998); the iterative function of a performance in a particular context that reflects (Richards 1993) and creates knowledge (Netting 1993); and the ways that farmers develop normative 
justifications that help them to order their experiences and provide acceptable ways to respond to social, economic, and ecological problems (Vanclay and Enticott 2011). Political ecology works on the subjective and material aspects of this performance, structuring the presentations of a self in this agrarian, development context and the flexibility by which knowledge is put to use in daily practice.

Extending the theatrical metaphor further, rural sociologists have analyzed the ways in which scripts, learned behaviors and justifications drawn from iterative learning, help to structure performances (Bardone 2013; Vanclay and Enticott 2011). During interviews, Telangana cotton farmers growing genetically modified (GM) cotton invariably justified their particular seed choice by saying: manci digubadi annakunthunnanu. This response, "I'm hoping for a good yield", is the obvious answer to a question about seed choice for a cash crop. But when viewed as an iterative performance, it is also a kind of script in that it provides a structured response, a way to justify a choice when such decisions are often made in the context of uncertainty. All such scripts help to construct world views and are reduced from them, thus limiting the range of options perceived to be available to performers (Vanclay and Enticott 2011).

Dramaturgical metaphors link these quotidian performances of knowledge and self to the larger expectations of development or modernity - essentially guiding a discussion of how one ought to live (Pandian 2009). In South India, these performances stem from a specific postcolonial history that demands certain kinds of progress, strategic presentations of self and knowledge, and uncomfortable, organizations of knowledge and identity. Agricultural development, especially in India where half the populations makes a living through agricultural work, has been a specific process of capital intensivity and industrialization. New technology always creates new authorities, experts, and subjects. These can constrain farmers' plans but they also afford opportunities in cultivating new and shifting benchmarks of modernity and development. Development, virtue, and cultivation, both of the self and of the landscape, are interconnected in this quest to live as one ought to live (Gupta 1998; Pandian 2009; Vasavi 1999). In this framing, agricultural development becomes a moral and material aspiration, whereby postcolonial subjects must develop and mature (Pandian 2011).

The performance of self is structured by power and expertise in this postcolonial framework (Ong 2010) as well as the iterative subversions and incomplete development benchmarks (Pandian 2011; Subramanian 2009; Tsing 2005). This complex stage impacts the daily practice of knowledge, and thus its iterative creation and adaptation. With its focus on knowledge and discovery, research in STS and postcoloniality further illuminates how knowledge, performance, and self overlap through a performed mêtis. STS scholars are often critical of Foucauldian approaches because they are too androcentric, missing the rhizomatic linkages and interconnections between Others and Selves or dominant and marginal discourses (Braidotti 2006; Haraway 2008). Yet, importantly for this essay, both Foucauldian and STS approaches draw attention to the construction of bodies and of knowledges as functions of biopower, reinforced by larger social constructions of truth and normality. Agriculture, informed by quotidian practice and gradual skilling processes, is therefore influenced by how farmers engage with the discourse of development, conceptualizing their agriculture as modern, progressive, or alternative. Viewing subjects as in a constant state of mutual composition (Latour 2010), in which one 'becomes with' the multitude of human and nonhuman actors (Haraway 2008) in the farm landscape asks that researchers link performances of self to material agricultural decisions - especially if we understand farming as a moral process engaged with competed discourses on modernity ( Escobar 2011; Pandian 2009). Each performance adjusts for variations in the audience and stage, because the process of creating, adapting, and translating knowledge on farms where farmers engage with agricultural development does not allow knowledge to be separated from the actors who engage with it (Stengers 2010). This nexus of subjectivity and daily practice is central to mêtis and thus to the daily practices that encompass agricultural knowledge.

To understand how improvisational agroecological decisions and presentations of self are performed in the field, I draw upon three case studies in farmer performance on cotton field in Telangana. The contingency of performance can be seen among those organic villagers that quit organic programs and by the precipitous decline of an intervention program offering remote advice. In organic villages that do not see the promised yield or infrastructural benefits from their participation, some leave the program or bend the rules. These farmers are by definition marginal to the project, less personally invested in its success or less socially connected to the program managers. Others, especially if they become personally invested in the program, learn to shape this form of development to their own interests, fulfilling development goals while masking the 
importance of their own performance and charisma in its success. The successes and failures of these different agricultural systems highlight the ways in which farmer development roles depend on the stages they are given. These performances influence how farmers come to see their place in postcolonial development as well as the daily management practices of agriculture.

\section{Parvathi and the failure to align interests}

In 2013, Prakruti ${ }^{2}$, an organic cotton company established a demonstration farm near the town of Japur, in northern Telangana. This farm served the dual purpose of organic ethical marketing, creating and advertising distinction in a value-added commodity chain, and redirecting profit toward explicit development initiatives that make cotton farming more sustainable. The farms are performative stages, constructed to show the promise of development to an audience of funders, retailers, scientists, and skeptical farmers. The space features English-language signage that explains common agricultural methods to visitors who, unlike the local farmers, speak English. During one tour with a representative from a World Bank affiliate and a Tamil clothing company, farmers explained that they earn extra money through a tool rental service, which recycles funds back into their cooperative village pot. But does organic agriculture affect your health, asked the visitors? "I want to understand if they really feel it", Tamil entrepreneur Kehan explained, referring to what she called the 'heart and soul' of organic. Finally, her prodding resulted in the right answer: "I switched to organic because I could see that it was bad for the environment", offered Japur's sarpanch. Satisfied, Kehan applauded.

Back in Hyderabad, I asked Prakruti employee Sama about these tours:

We don't give any kind of orientation to the farmers. Since 2004 they are getting visitors so all the farmers are versed in the practices. Of course sometimes there are deviations and all, or sometimes they don't want to do it, or sometimes they feel that now this [Prakruti] support is not sufficient. But on the whole people like the program so actually when visitors come they explain it...If we have [an event like planting mango trees] to encourage the buyers, they should feel like they did something good... And when they come again we will take them to that place.

Over time the repeated visitation, the expectations of audiences of visitors and development workers, not to mention the changing resources under organic agriculture conditions, can reinforce stages, scripts, and performers. But this performance is always contingent upon the stage: the socioeconomic incentives and reward structures of the alternative program. In 2012, fifteen households in Japur began a mandatory three-year conversion process to transition to certified organic agriculture. By the following year the farmers were generally irritated with Prakruti. We only do this, one farmer grumbled, "because Prakruti is giving us cheap seeds, but the yields are poor and the profit margins are even worse: a small premium combined with a small yield. Their rules are complicated, they are banning the [fertilizers that would give a] solution [to the yield problem], and if we use them they won't take our cotton." To satisfy the certification requirements of foreign buyers, organic farms follow procedures outlined by the United States Department of Agriculture, which have become a template for organic production around the world. Prakruti cannot sell organic cotton as such or provide the promised premiums until after a three-year transition period, placing farmers in an uncomfortable double-bind where they must suffer comparatively lower yields from non-GM seeds grown without chemical inputs and receive no price premium. Contrary to that farmer's perception, Prakruti does buy non-organic cotton and sell it on the open market, but the farmer is correct to note that his family receives no additional income for the trouble of organic production.

In 2013, with the continued support from the company through government assistance, farm equipment, seeds, and training programs, the Japur farmers were willing to humor the management demands placed upon them. Yields are bad, explained Parvathi, head of Japur's women's self help group (SHG). Like cooperatives and village societies, SHGs have emerged in India as a useful democratic village-level political force for women, and a convenient promotional tool for gender equality oriented NGOs. But, she continued, the cotton

${ }^{2}$ All village, organization, and interlocutor names have been changed. 
yields were bad in the past as well. "Now we have the sprays from Prakruti and we know how to plow and properly prepare the cow manure", she continued, performing a transition from ignorance to enlightenment that Escobar (2011) and Gupta (1998) have documented in development contexts. "The DAP and urea hurt the land and cause it to lose energy", said another, repeating a Prakruti talking point I heard in all the villages. "Now we know better". Not all farmers shared their enthusiasm. Five households did not know the names of the seeds that they planted, claiming that "Prakruti gives the seeds, we take what they give and we don't use chemicals on that land." Upon further investigation, some of these farmers were planting GM cotton seeds, purchased from local shops or brokers. Under international regulations, GM cotton cannot be certified as organic regardless of the conditions under which it is grown, representing a potential complication for the company and for farmers. Returning to the office after a day of interviews, I mentioned that a number of Japur farmers were planting GM seeds, an infraction that could violate the letter, if not the spirit, of organic production regulation. Arjuna, the NGO's district coordinator, grew irritated and advised me to try other farmers where I could find "better information." "Don't talk to them, they are only transitioning", he informed me. After all, what organization would not rather have visitors see their best rather than their most marginal farmers? "Oh, it's no problem", I said, feigning ignorance of his discomfort. "This will help me understand how farmers make the jump to organic cotton."

By 2014 that optimism had evaporated. "Prakruti stopped giving so we stopped taking" shrugged Parvathi. "We tried organic for three years", she explains: "In the first year it came very well, but they kept giving the same seed. The yield went from fifteen, then ten, and then last year two quintals per acre (494 kg/ha). It's probably a fault of the manufacturer rather than Prakruti, but we don't want to take from them anymore." I found myself back in the office expressing my surprise that all but two of the Japur farmer households had dropped out of the program. "They are defaulters", lamented Arjuna. For three years the farmers took loans, plants, farm equipment including plastic drums, seeds, and participated in a government assistance program brokered through Prakruti. For three years they claimed that they could not afford to pay back their debts to the program. "We couldn't pay", says Parvathi. "We lost the entire crop last year and there was nothing to be done." As a farmer of over twenty acres ( $8.1 \mathrm{ha}$ ) and the owner of a local shop, I have doubts that she could not have repaid her debts on four acres of cotton (1.6 ha), but she refuses to do so.

The partnership broke down, in part because of how Parvathi and Arjuna conceptualized development. Parvathi, less invested in the environmentalist schemes of the organization and frustrated with low returns from organic cotton agriculture saw a saving grace in zero interest loans that supported her shop, the only source of gasoline, staple foods, oils, and other household needs in her hamlet. Arjuna, beholden to the business needs of satisfying customers and making a return on his company's investment, was ultimately less interested in working with Parvathi to sustain her shop and was irritated by her refusal or inability to repay their loans. "They're still interested" mused Arjuna, "but we've stopped giving them things as they aren't paying us back." The combination of heavy rains during last year's harvest and the late El Nino monsoon of 2014 led many farmers to question his efforts. Later in our conversation, he confides that in such difficult years he must keep a closer watch on all the farmers, especially those in her Scheduled Tribe community, to ensure their compliance in spite of their repertoire of agroecological knowledge:

These Tribal farmers, you can't just say once, you have to say two, three times, and you have to show them everything. That's why the [demonstration] land is so important. They have gotten trainings on insects and sprays and soil, and now those things are improving, but we need to give them training in business too. This area is very good for the organic farming because we can show them what to do and how to do it. That support is necessary.

In 2014, only four out of twenty-four cotton seed choices in the village, representing two farmer households, planted seeds eligible for organic certification under the program rules.

Farmers who give the 'right' answer to visiting donors and visiting anthropologists like myself recognize that their answers can open or close access to resources. More subtly in this context, as farmers continue to perform this oversight, their internal governance of 'right' answers and 'right' practices reinforces the 
performance of the 'right' identity. By changing the systems of incentives and constraints in agriculture through their organic development program Prakruti facilitated new internal environmental governances, not unlike the internal surveillance that Agrawal (2005a) describes as environmentality on North Indian forest conservation councils. Performance, whether of an environmentalist watchdog or of a transformed and rule-abiding farmer, keeps people on the stage - the new political and economic contexts of the development program.

However, as shown by Parvathi's performances, these new internal systems are not permanent and they do not erase internal hierarchies and local struggles for control. Viewing oversight as a performance brings these contingencies to light. While addressing these local fissures in other works, (Agrawal and Sivaramakrishnan 2000), Agrawal's failure to account for the ways that caste, gender, class, and other local social distinctions impact the daily implementation of governmentality has been a significant critique of his work (Agrawal 2005b). Arjuna dismisses Parvathi's concerns and practices in part because she is a woman, in part because she is more interested in sustaining her shop than in sustaining the organic program, and in part because she belongs to a scheduled Tribe, a historically marginalized group in Telangana. Prakruti erred when it mistook the contingent performance for a sustainable environmentality, in part because the social performance of transformation was too strongly tied to external rewards rather than quotidian practice.

In the absence of clearly defined rewards, and considering their own poor experience with the seeds, the organic farmers in Japur no longer had any reason to talk about their transformation and the education they received at the hands of the program. While she was engaged with the program, Parvathi's performance of a transformed self in touch with the environmentalist development of Prakruti influenced how she spoke to me and to other visitors, how she farmed, how she framed her decisions about her work and her responsibilities to the larger village, and thus shaped the kinds of knowledge she built. But like all performances, it was contingent to the audiences and needs at hand. When the program ceased to offer benefits as Parvathi and other important stakeholders in the village recognized them, she began new subjective and agricultural performances. As this audience changed, the internal governance that she helped to oversee collapsed and the agrarian landscape began to revert to the capital-intensive agriculture common in the rest of Telangana.

\section{E-Digu and the failure to recognize social learning}

Certified organic agriculture demands direct oversight as a part of its auditing process, and so it engenders performances in line with environmentalism and ethical consumption. In other interventions, the stage is set by more by opportunism. Conventional farmers planting GM cotton in Telangana's Warangal district were happy to take free advice from the consulting program E-Digu, and to declare the program a success. For farmers, the performance of gratitude and transformation from ignorance to development was an improvisation in response to this new incentive - just as useful as saving a drought-tolerant seed in response to a water shortage or shifting fuel when burning a swidden field. E-Digu indicated that they had saved farmers money, improved their scientific understanding of agriculture, and helped to bring technology from high-tech "Cyberabad" to the impoverished agrarian countryside of the Telangana region (Stone 2011b; Uday Kiran et al. 2010). Frustrated with what they saw as an ineffective extension service, university-based computer scientists in Hyderabad sought to provide a better service whereby each farmer could pay to receive knowledge about their specific problems regularly through the growing season. As founder P. Rao explains, his goal was to:

...help the farmer [such that] the farmer doesn't even ask the question. That is very important in the Indian context - nobody will ask the question...The farmers are those who are illiterate, who have not studied. The Government support systems] are reaching only the elite farmers, not poor farmers. We have [historically marginalized Scheduled Caste (SC) and Scheduled Tribe (ST)] farmers, you know. Knowledge is not reaching them.

In our interview, Rao emphasized that his program fills a gap in farmer knowledge, one unfilled by lackluster government programs. This is a view of knowledge not as the result of different kinds of performances, but as an absolute truth there to be realized. In Greek terms, this is the difference between 
epistêmê or technê, knowledge that articulates with universal scientific understand and can be easily transferred to new contexts, and mêtis, the knowledge emergent from contingent, improvised performance. Reaching thousands of farmers and winning numerous accolades, the project has shifted from a very personalized approach where individual farmers interact with scientists remotely to a more manageable and scalable approach where farmers solicit scientists one on one in local villages, and pay for that service. Yet in ignoring the role of performance, both of gratitude for the technology and of improvised agricultural responses, E-Digu faced serious problems when they restructured their advice system.

"We achieved the target", explains Rao, and so "it must be replaced now." This replacement is necessary, he continues, because he "the farmers are overconfident" in their own knowledge and experience. When E-Digu switched from free advice to a pay system in 2008, official farmer enrollment in the program dropped from more than 7,000 to just above 1,000; the staff dropped from 80 to six workers including only one full time field worker; and the actual extension work has gone from individual consultations to a notice board that informs farmers about general agricultural problems. The same project that won Rao's team awards and media attention had essentially collapsed due to a lack of farmer interest in the absence of free advice.

Village coordinator Raji recalls that the current version of E-Digu was first tested in 2007 in the village where Rao had been born, serving 300 paying farmer customers. But after five years, Raji concluded that the constituents had learned "too much" because no one was interested in paying to hear the same advice as in years past. In 2014, only ten people asked for forty discrete solutions, totaling Rs 2,000 [US\$33) at Rs 50 [US\$0.83) each. To put this in perspective, Raji's salary is set at Rs 4,000 [US\$66.67) per month plus Rs 1,000 [US\$16.67) for petrol expenses, meaning that the project last year incurred a net loss of Rs 43,000 [c.US\$660) during his nine month stint. Why, I asked, did the farmers stop paying? As Rao recalled:

In the first year [of large scale payment plans] 200 farmers paid. The second year it came down to 100 . The third year it came down to thirty or forty per village. That means thirty or forty farmers will pay. Then I called the farmers, these SC, ST poor farmers, I said I am closing the system. So they said, why are you closing? Because you are not paying! You are not paying and government is not providing [funds to cover the balance]. No sir, we are following your advice. Everybody in the village is following your advice. How? How are you following? We are copying their advice. Those thirty farmers who are paying, we are copying [from them]...It's the anthropological problem. Everything is perception. What do you perceive? [The farmers] don't perceive the reality.

Farmers were happy to accept lessons and profess their gratitude to the E-Digu team during an initial burst of scientific expertise as long as E-Digu provided assistance without strings attached. However, as soon as this learning became expensive and their perceived rewards diminished, farmers fell back on a kind of social learning that would efficiently move scientific expertise through the village when needed. Rao claims that the farmers didn't perceive the reality of E-Digu's continued value, but it is also true that his interventions were simply overrun by the cheaper and equally reliable social emulation. What farmers appeared to like about the stage set by E-Digu - that it provided a source of free information that could be called upon as part of the patchand-mend toolkit - had disappeared in this newest iteration. Farmers were willing to go along with Rao's lessthan-generous presentation of them as ignorant and underdeveloped, but they abandoned this approach when asked to pay for knowledge that was only part of their larger agricultural management strategy.

The daily practice of agriculture and of self, what sociologist Erving Goffman (1959) would have called a front, together compose the people, practices, and iterative course corrections that result in knowledge. But knowledge and self are neither fixed categories nor separate from one another in the field. This oversight led to problems in Prakruti and E-Digu's programs. Viewing knowledge more as a negotiation, as I will show in the final case study, allows for a greater variety of course corrections. It also accounts for the performer's needs and aspirations. E-Digu hoped that knowledge would be completely separate from the farmers and fields where it was practiced, and accepted farmer gratitude as a state of nature rather than as a performance. 
As with Parvathi and Prakruti, development intermediaries failed to see farmer practices as contingent on the audience and the local reward structure. In both cases, farmers were frustrated and irritated when offfarm experts changed the stage, and their performances changed as a result. In neither case were farmers and intermediaries able to align their interests. In the final case study, farmers and intermediaries were able to mutually compose relationships that accounted for local and NGO visions of development.

\section{Mahesh and the benefits of celebrity}

A combination of personal charisma, social status, and public recognition makes some farmers ideal performers because their actions carry more weight in the village. The institutional need for a charismatic villager created space for one such celebrity to rise and in so doing, shape the narrative and benefits of organic intermediation to his and a non-certified organic NGO's mutual interest. "[Mahesh is] a very knowledgeable person and a good leader who could mobilize the village. We always feel such charismatic leaders are important", explained Ramesh, executive director of PANTA, the sponsoring NGO for Ennepad's organic agriculture. Mahesh can be found in virtually every media piece on the story of organic agriculture in Ennepad village (Misra 2009; Podamu 2014), and even creeps into academic writing (Desmond 2013; Quartz 2010). Walking through Ennepad for the first time I was told, "You don't want to talk with me, go talk with Mahesh. He knows everything." While his expertise makes him a fascinating interlocutor, the way in which Mahesh comes to represent the village, or the way in which the village is used to represent organic production generally, is misleading. This elision is especially troublesome because it hides the show and performative aspects that make his farm so successful. They are not, in this political ecology sense, naturally superior, but are sustained by a thick social network of expertise and support.

Mahesh is old enough to have given away most of his land, but remains a stalwart and photogenic farmer in his remaining acres. Other farmers in the village urge visitors like me to talk to him and leave them alone. He immediately recognized me and my own performances for what I was and what I represented. I carried a clipboard, the tell-tale sign of a visiting researcher, and as I explained my research goals I was careful to emphasize how his story might help other villages benefit and learn from his example. Mahesh listened carefully, weighing the likelihood that spending hours with me would be worth his time. As a visiting researcher trying to shape his story to my own academic narrative, I could bring him more acclaim or contest his version of events in the village. "Write a book about us", he demanded one morning over tea.

Like all such "show farmers" (Flachs 2017; Stone 2014), Mahesh was instrumental not only when PANTA wanted to gain trust in the village but also when they needed to adapt agricultural theory to local practice. When I asked if the NGO used any of his suggestions, Mahesh grinned. "They sucked my knowledge out like a straw. They give good advice and help", he said, but, "it's mostly all from me." He is not merely bragging - Mahesh helped adapt the pest-traps and non-chemical fertilizers now standard in the village, and he continues to advise the NGO on new management strategies. Beyond this, Mahesh is useful to the narrative of the pristine organic village in that he uses non-mechanical, non-chemical, and non-industrial methods that no one else in Ennepad uses. He is the only farmer to consistently produce his own seeds or cow manure fertilizer. These labor and knowledge intensive practices are irrelevant in Ennepad, where the NGO provides free nonGM seeds and operates a shop where farmers can buy organic inputs. However, Mahesh has no interest in these perks. "With your own seeds", he contends, "you can be sure of what you're planting and better predict how it will work." Cotton seed breeding is difficult, unnecessary work in a village where an NGO gives seeds to farmers for free. Yet that work perpetuates the narrative that farmers, symbolized by Mahesh, eschew the trappings of modernity (Misra 2009). When I asked Mahesh who bought seeds from shops or the NGO he scoffed, "those with no patience." In practice, 58 of the 69 cotton seeds planted by Ennepad farmers in 2012 and 2013 were purchased.

As we toured his farm, I complimented his fields and laughed at his jokes. In turn, Mahesh played up his own innovations and celebrity, emphasizing how much his efforts have transformed the village. Both of our performances reflect a deeper shared stage. His farm is impressive and I found his jokes amusing, but Mahesh was able to show me how he pushed the village toward organic agriculture because of my own research agenda and the socioeconomic security that PANTA has provided his farm. Our performances are not insincere, 
but they reflect the larger sociopolitical context. On the farm, it is analytically interesting that Mahesh's celebrity has become one of his defining characteristics, even to the exasperation and jealousy of his neighbors. PANTA has provided an alternative means for fulfillment in this village, and Mahesh has been able to take full advantage of this redefined success (Flachs 2016). Over his years of experience troubleshooting organic agricultural methods and cultivating his celebrity, Mahesh has been able to practice, improvise, and thus create new kinds of agroecological knowledge. Unlike Prakruti or E-Digu, Mahesh and PANTA accepted change and failure as a part of their mutual learning process and have committed to a long term partnership that values multiple definitions of development.

Of the three development models, PANTA is the most institutionally flexible as it relies on local direct sales and media narratives rather than state certification or short-term grants to add value to farmers' products. Ennepad sits a twenty minute walk past another village, also full of farmers. "Are you going to Ennepad?" asked village teenagers passing on the way to the main road. When I answered in the affirmative they rolled their eyes and laughed. "Everyone always goes to them, no one ever comes to see us. They spray at night." Inter-village jealousy aside, several farmers admitted spraying pesticides in extreme situations and I noticed pesticide bottles in household trash piles. In 2013, at least six farmers in Ennepad admitted to planting GM seeds after repeated field visits. One farmer claimed to plant non-GM and proudly showed me a seed package, labeled Dr. Brent Bt Cotton, a GM seed. When I pointed out that this was a GM seed, she told me, "GM, nonGM - you can read and I can't, you tell me." PANTA had not provided her with seeds that year and in the absence of their advice she went with a shop suggestion. The whole village, she says, does this when they don't get seeds from PANTA. Repeating an erroneous but oft-spoken conception, that GM cotton had some kind of poison in it that would harm the soil, one farmer fell into interesting double speak: "It's a chemical and we shouldn't keep it, but it makes the cotton grow well. It'll poison you if you touch it every day even if the production is more. You have to rotate with GM as it poisons the field: if goats eat it they lose their hair and the same thing happens to the soil." "But you just said you put it in your own fields", I protested. "I was late getting the seed", he explained, saying that he was planting it without telling PANTA. "Okay", I said, "I won't tell either", and he grinned sheepishly.

Dramaturgical metaphors are especially helpful in this understanding of knowledge, as they consider stages, actors, contingent roles, audiences, and scripts to be the building blocks in learning. Goffman's insights $(1956,1959)$ draw attention not to the individual, which would be farmers in interventions, so much as the interaction between the individual and the audience, which would include the intervention teachers and other farmers. When an organic program gives farmers seeds or subsidizes certain kinds of management, many farmers feel that it is more important to learn how to continue working with the intervention than to learn which agricultural method or seed is best - a matter of deference and presentation as much as deep-seated transformation. Such questions are irrelevant when the production risks are essentially underwritten by the program. However, by learning to perform, farmers can find themselves speaking to crowds of politicians, media, researchers, and interested peers, demonstrating their methods to a rapt audience. By learning to present the right kind of self, a transformed, scientific, business-savvy self, farmers can secure both economic rewards and social recognition. These performances involve both planning and improvisations amidst a host of social and agricultural variables.

To understand these performances in context, I suggest that philosopher David Schön's work on the reflexive practice of architecture and urban planning provides an ethnographically grounded examination of the tension between planning and improvisation $(1983,1987)$. Schön observed that architects and clients have to learn to compromise on their visions, share expertise, and above all recognize that expert intervention frequently misses the mark in practice, requiring reformulations that meet the needs of a wide set of stakeholders. Presaging Scott's investigation into mêtis, Schön observed that the most successful expert practitioners recognized the value of improvisatory quotidian performance:

When we go about the spontaneous, intuitive performance of the actions of everyday life, we show ourselves to be knowledgeable in a special way. Often we cannot say what it is that we know. When we try to describe it we find ourselves at a loss, or we produce descriptions that are 
obviously inappropriate. Our knowing is ordinarily tacit, implicit in our patterns of action and in our feel for the stuff with which we are dealing. It seems right to say that our knowing is in our action" (Schön 1983: 49, emphasis in original)

Much as the agricultural interventions described above encountered difficulties in matching their expert visions to the needs of everyday life, Schön argued that interventions that dismiss this quotidian expertise would likely fail.

Mêtis and reflective practice both depend on reflection in the moment, the calculated and improvised re-evaluation of decisions, judgement criteria, procedures, and the way in which problems are framed. Midperformance, these reflections on both the ecological performance in the field and the kinds of cultivated showmanship described in this essay inform farmers' future and ongoing decisions as they "find their groove" (Schön 1983: 55). This process results from iterative course-corrections and the ever-changing constraints and opportunities offered to farmers through the development apparatus. By reflecting and adjusting their rules, development practitioners impose constraints on farmers, but they too are constrained by the larger social norms in rural India, the rules of organic production, and the support of local agricultural bureaucrats. As everyone involved learns to speak and work with each other, this negotiation process itself shapes the course of future discussions. In turn, this legitimates other possible futures, encouraging members of the community to share different expertise and concerns at different times throughout the process. Just as Richards warned against taking trial fields at face value, Schön (1987) warns that pre-conceived designs are in practice inherently unstable, oscillating between constrained planning and improvisatory decision-making. In a farm field, such re-framings are mutually composed by all stakeholders, including experts, farmers, and ecological constraints (Latour 2010). When planning or political ecological constraints become inflexible, including the demands of certification or the opportunities of the market, farmers leave programs or pay lip service to development initiatives, baffling experts who assumed that their work was proceeding well.

Both Mahesh and rule-bending farmers perform improvisations in their farm, and in both cases the freedom of PANTA's non-certified support allow them to improvise in response to new problems, learn from their results, or, in the case of the farmers above, make do with suboptimal resources in a pinch. In turn, the NGO's willingness to learn from Mahesh and recognize that farmers would not always be able to follow their instructions left the lines of communication open. Mahesh continues to perform the role of a creative success story, other farmers perform a gratitude that cracks under scrutiny, and everyone can perform in their field without fear of retribution from their sponsor. This is the difference between reflexive and rigid practices, and it has an agrarian consequence. Where E-Digu and Prakruti have largely ceased working in the examples above, PANTA continues to provide logistical support and to benefit from the performances and narratives of partner farmers.

\section{Taking transformation seriously}

Performance is social work. The characterization of farmer actions as performances is not to suggest that these are insincere lip service. Roles must be learned and practiced, and some farmers are better performers than others. As illustrated by farmers in various intervention programs professing their prior ignorance of field management and business, Escobar (2011) and Agrawal (2005a) are correct to note that people adjust the way in which they talk about themselves and their work to align with the incentives and new knowledge of experts when encountering development. To whatever extent that this performance breaks down under ethnographic scrutiny, farmers learn to take advantage of the organic program, seed shop, extension office, or call center just as they process environmentally learned information about seed choices from their own fields and socially learned information from the fields of their neighbors. Narratives of transformation and gratitude emerged in all three cases. These narratives order farmers' experiences with alternative agriculture and respond in legible terms to an expectant audience, what rural sociologists call a script ( Bardone 2013; Vanclay and Enticott 2011). Such scripts cement the expected development response in this postcolonial context, one of gratitude and rational choice (Escobar 2011), even and especially when the farmers are not totally convinced by the narrative. 
The agricultural development programs described here rely on farmer performances to shore up political and financial relationships. Farmers who are more closely linked with state extension programs are more legible, while those who can speak eloquently about NGO programs provide funders and donors with a clear benchmark of their funds' impact. As has been well documented, performances of transformation (even shortlived performances such as those documented here), environmental governance, or simply the acknowledgement of underdevelopment brings in new forms of regulation and legibility but does not always bring sustainable, holistic benefits to poverty or environmental degradation (Agrawal 2005a; Escobar 2011; Ferguson 1994; Scott 1998). As these and other case studies show, farmers' performances reflect the contingent reward structures of the new development program - the stage (Agrawal 2005a; Gupta 1998; Pandian 2009; Vasavi 1999). Yet, these performances are also part of the daily practice of agriculture and become part of the repertory knowledge discussed by Batterbury (1996) and Richards $(1989,1993)$. A farmer who can rely on subsidies and extension programs, or who knows that they are obligated to go along with an untested new practice must build on their quotidian agricultural skill through these socio-agricultural constraints. Here the clear differentiation between performer and performance becomes blurred. These performances of transformation or fears of chemical contamination become part of a learning process in a socially embedded agriculture.

Learning to perform roles in this environment rests on the incentives and constraints embedded with different programs. The ways that farmers learn to earn benefits by playing development roles becomes just as important a repertory of agricultural knowledge as learning to manage one's field or copying one's neighbors. Stone (2016) notes that didactic interventions often seek to claim that corporate, NGO, or government technology aligns with farmer interests, notably yield or profit. However, as demonstrated by the discussion above, the larger success of such technologies depends on how farmers integrate that opportunity into their larger performance. If and when development schemes or technologies limit improvisational responses or conflict with local aspirations, the opportunities for performances of self or of agriculture are similarly limited.

The roles that farmers play depend on the stage they are given: in the presence of economic or material rewards, as well as the added social recognition and sense of celebrity that comes from being regularly interviewed and photographed with visitors, farmers learn to perform and even embody the sense of transformation. In performing this transformed sentiment, farmers learn not only agricultural methodology but how to cultivate a kind of celebrity that maintains the flow of social and economic resources in tandem with the intervention program. If that role then conflicts with local aspirations, farmers are likely to abandon those development projects. This performance is sustainable only so far as it is mutually composed and sustained by farmers, intermediaries, and the needs of agriculture.

\section{References}

Agrawal, A. 2005a. Environmentality: technologies of government and the making of subjects. Durham: Duke University Press.

Agrawal, A. 2005b. Environmentality: community, intimate government, and the making of environmental subjects in Kumaon, India. Current Anthropology 46(2): 161-190.

Agrawal, A. and K. Sivaramakrishnan (eds.). 2000. Agrarian environments: resources, representations, and rule in India. Durham: Duke University Press.

Alcorn, J.B. and V.M. Toledo. 2000. Resilient resource management in Mexico's forest ecosystems: the contribution of property rights. In F. Berkes, C. Folke and J. Colding (eds.). Linking social and ecological systems: management practices and social mechanisms for building resilience. Cambridge: Cambridge University Press.

Bardone, E. 2013. My farm is my stage: a performance perspective on rural tourism and hospitality services in Estonia. PhD dissertation. Tartu: University of Tartu Press.

Batterbury, S.P.J. 1996. Planners or performers? Reflections on indigenous dryland farming in northern Burkina Faso. Agriculture and Human Values 13: 12-22.

Baudrillard, J. 1981. Simulacra and simulation. Ann Arbor: University of Michigan Press. 
Braidotti, R. 2006. Posthuman, all too human: towards a new process ontology. Theory, Culture \& Society 23(7-8): 197-208.

Brookfield, H.C. 2001. Exploring agrodiversity. New York: Columbia University Press.

Butler, J. 1990. Gender trouble: feminism and the subversion of identity. 1st edition. New York: Routledge.

Desmond, E. 2013. The legitimation of risk and democracy: a case study of Bt cotton in Andhra Pradesh, India. PhD Dissertation. Cork: University College Cork.

Escobar, A. 2011 [1995]. Encountering development: the making and unmaking of the third world. Princeton, N.J.: Princeton University Press.

Ferguson, J. 1994. The anti-politics machine: 'development,' depoliticization and bureaucratic power in Lesotho. Minneapolis: University of Minnesota Press.

Flachs, A. 2016. Redefining success: the political ecology of genetically modified and organic cotton as solutions to agrarian crisis. Journal of Political Ecology 23(1): 49-70.

Flachs, A. 2017. "Show farmers": transformation and performance in Telangana, India. Culture, Agriculture, Food and Environment 39(1): 25-34.

Forster, D., C. Andres, R. Verma, C. Zundel, M.M. Messmer and P. Mäder. 2013. Yield and economic performance of organic and conventional cotton-based farming systems - results from a field trial in India. PLoS ONE 8(12): e81039.

Freidberg, S. 2004. French beans and food scares: culture and commerce in an anxious age. Oxford: Oxford University Press.

Goffman, E. 1956. The nature of deference and demeanor. American Anthropologist 58(3): 473-502.

Goffman, E. 1959. The presentation of self in everyday life. 1st edition. New York N.Y.: Anchor.

Gregson, N. and G. Rose. 2000. Taking Butler elsewhere: performativities, spatialities and subjectivities. Environment and Planning D: Society and Space 18(4): 433-452.

Gupta, A. 1998. Postcolonial developments: agriculture in the making of modern India. Durham: Duke University Press.

Haraway, D. 2003. The companion species manifesto: dogs, people, and significant otherness. Chicago: Prickly Paradigm Press. Section

Haraway, D. 2008. When species meet. Minneapolis: University of Minnesota Press.

Heller, A. 2018. Fistula politics: birthing injuries and the quest for continence in Niger. New Brunswick: Rutgers University Press.

Ingold, T. 2011. The perception of the environment: essays on livelihood, dwelling and skill. London: Routledge.

James, E.C. 2010. Democratic insecurities: violence, trauma, and intervention in Haiti. Berkeley: University of California Press.

Latour, B. 2010. An attempt at a "compositionist manifesto". New Literary History 41(3): 471-90.

Leslie, P. and J.T. McCabe. 2013. Response diversity and resilience in social-ecological systems. Current Anthropology 54(2): 114-143.

Ludden, D. 1999. An agrarian history of South Asia. Cambridge: Cambridge University Press.

Misra, S.S. 2009. Riding high. Down To Earth Magazine Jan 1-15: 21-28.

Netting, R.M. 1993. Smallholders, householders: farm families and the ecology of intensive, sustainable agriculture. Stanford: Stanford University Press.

Ong, A. 2010. Spirits of resistance and capitalist discipline: factorywomen in Malaysia. 2nd ed. Albany: State University of New York Press.

Pandian, A. 2009. Crooked stalks: cultivating virtue in south India. Durham: Duke University Press.

Pandian, A. 2011. Ripening with the Earth: on maturity and modernity in South India. In S. Dube (ed.) Modern makeovers: a handbook of modernity in South Asia. New Delhi: Oxford University Press. Pp. 157-169.

Qaim, M. 2003. Bt cotton in India: field trial results and economic projections. World Development 31(12): $2115-2127$. 
Quartz, J. 2010. Creative dissent with technoscience in India: the case of non-pesticidal management (NPM) in Andra Pradesh. International Journal of Technology and Development Studies 1(1): 55-92.

Richards, P. 1989. Agriculture as a performance. In R. Chambers, A. Pacey and L.A. Thrupp (eds.). Farmer first: farmer innovation and agricultural research. Rugby: Intermediate Technology Publications. Pp. 39-42.

Richards, P. 1993. Cultivation: knowledge or performance? In M. Hobart (ed.). An anthropological critique of development: the growth of ignorance. London: Routledge. Pp. 61-78.

Sainath, P. 2013. Over 2,000 fewer farmers every day. The Hindu, 2 May.

Schieffelin, E.L. 1998. Problematizing performance. In F. Hughes-Freeland (ed.) Ritual, performance, media. New York: Routledge. Pp. 199-212.

Schön, D.A. 1983. The reflective practitioner: how professionals think in action. New York: Basic Books.

Schön, D.A. 1987. Educating the reflective practitioner: toward a new design for teaching and learning in the professions. San Francisco: Jossey-Bass.

Scott, J.C. 1998. Seeing like a state: how certain schemes to improve the human condition have failed. New Haven: Yale University Press.

Podamu, Palleku 2014. Selection of quality seeds for vegetation. Express TV. https:/www.youtube.com/watch?v=W06ingqSSsQ\&feature=youtube_gdata player.

Stengers, I. 2010. Cosmopolitics I. Minneapolis: University of Minnesota Press.

Stone, G.D. 2011a. Field versus farm in Warangal: Bt cotton, higher yields, and larger questions. World Development 39(3): 387-398.

Stone, G.D. 2011b. Contradictions in the last mile: suicide, culture, and e-agriculture in rural India. Science, Technology \& Human Values 36(6): 759-90.

Stone, G.D. 2014. Theme Park Farming in Japan. Fieldquestions. Blog. https://fieldquestions.com/2014/06/05/theme-park-farming-in-japan/

Stone, G.D. 2016. Towards a general theory of agricultural knowledge production: environmental, social, and didactic learning. Culture, Agriculture, Food and Environment 38(1): 5-17.

Subramanian, A. 2009. Shorelines: space and rights in South India. Stanford: Stanford University Press.

Sumberg, J.E. and C. Okali. 1997. Farmer's experiments: creating local knowledge. Boulder, Colorado: Lynne Rienner Publishers.

Tsing, A.L. 2005. Friction: an ethnography of global connection. Princeton: Princeton University Press.

Turner, V. 1970. The forest of symbols: aspects of Ndembu ritual. Ithaca: Cornell University Press.

Turner, V. 1980. Social dramas and stories about them. Critical Inquiry 7(1): 141-68.

Uday Kiran, R., P.K. Reddy, M. Kumara Swamy and G.S. Reddy. 2010. Analysing dynamics of crop problems by applying text analysis methods on farm advisory data of eSagu. International Journal of Computational Science and Engineering 5(2): 154-164.

Vanclay, F. and G. Enticott. 2011. The role and functioning of cultural scripts in farming and agriculture. Sociologia Ruralis 51(3): 256-271.

Vasavi, A.R. 1999. Harbingers of rain: land and life in South Asia. Oxford: Oxford University Press.

Vernant, J.-P. and M. Detienne. 1991. Cunning intelligence in Greek culture and society. Chicago: University of Chicago Press.

West, P. 2012. From modern production to imagined primitive: the social world of coffee from Papua New Guinea. Durham: Duke University Press.

Wilken, G.C. 1987. Good farmers: traditional agricultural resource management in Mexico and Central America. Berkeley: University of California Press. 